Provided for non-commercial research and education use. Not for reproduction, distribution or commercial use.

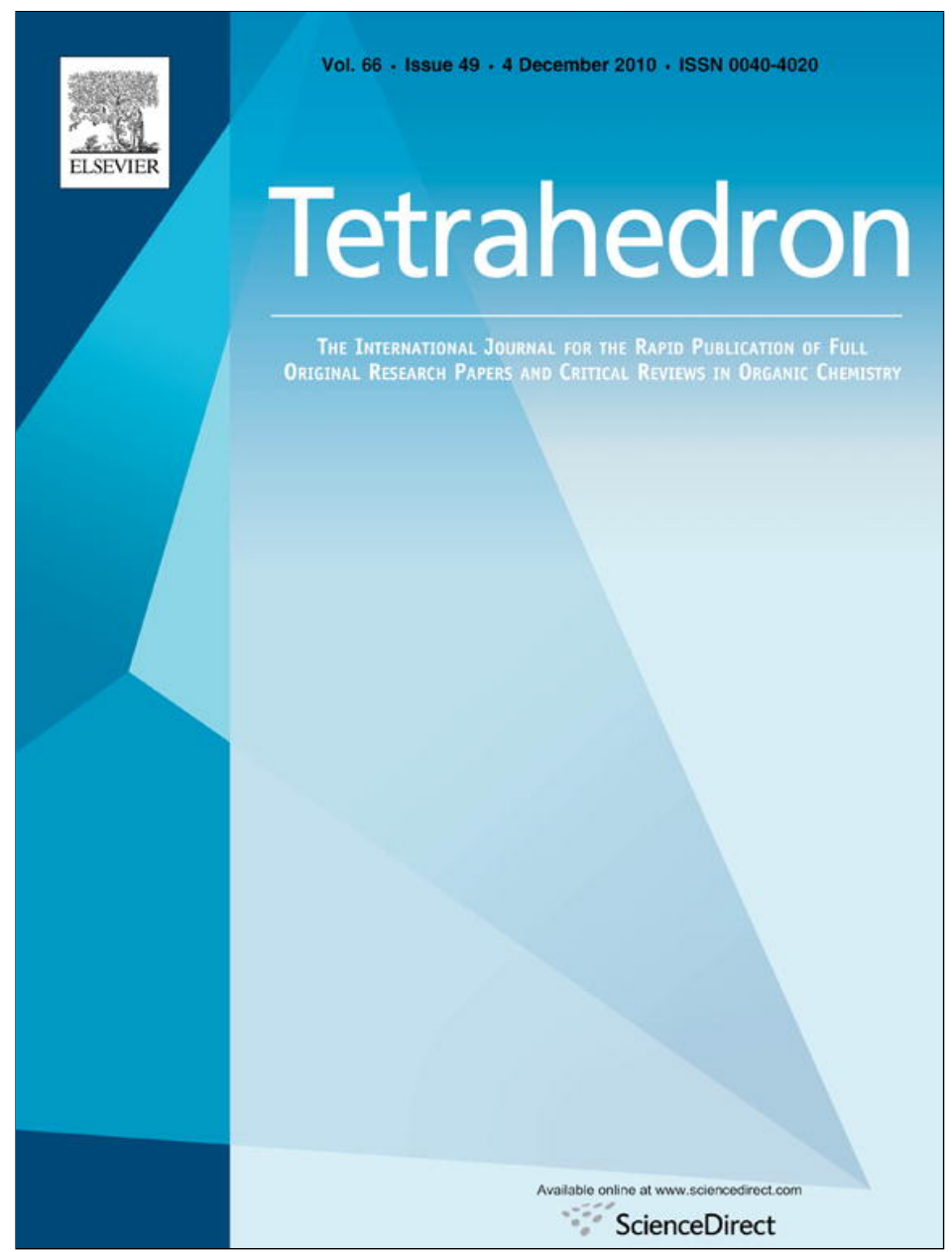

This article appeared in a journal published by Elsevier. The attached copy is furnished to the author for internal non-commercial research and education use, including for instruction at the authors institution and sharing with colleagues.

Other uses, including reproduction and distribution, or selling or licensing copies, or posting to personal, institutional or third party websites are prohibited.

In most cases authors are permitted to post their version of the article (e.g. in Word or Tex form) to their personal website or institutional repository. Authors requiring further information regarding Elsevier's archiving and manuscript policies are encouraged to visit:

http://www.elsevier.com/copyright 


\title{
Cyclodimerization by ring-closing metathesis: synthesis, computational, and biological evaluation of novel bis-azetidinyl-macrocycles
}

\author{
Aline Sliwa $^{\mathrm{a}}$, Georges Dive ${ }^{\mathrm{b}}$, Jean-Louis Habib Jiwan ${ }^{\mathrm{a}}$, Jacqueline Marchand-Brynaert ${ }^{\mathrm{a}, *}$ \\ ${ }^{a}$ Institute of Condensed Matter and Nanosciences, Université catholique de Louvain, Place Louis Pasteur 1, B-1348 Louvain-la-Neuve, Belgium \\ ${ }^{\mathrm{b}}$ Centre d'ingénierie des Protéines, Université de Liège, Bâtiment B6, Allée du 6 Août, 4000 Sart-Tilman (Liège), Belgium
}

\section{A R T I C L E I N F O}

\section{Article history:}

Received 17 August 2010

Received in revised form 28 September 2010

Accepted 8 October 2010

Available online 14 October 2010

\section{Keywords:}

RCM

$\beta$-Lactams

Cyclodimers

B3LYP calculations

R39 inhibitors

\begin{abstract}
A B S T R A C T
During our research on novel, non-traditional, bicyclic $\beta$-lactams as potential inhibitors of Penicillin Binding Proteins (PBPs), we focused on the synthesis of 1,3-bridged 2-azetidinones by RCM reaction from 1,3-bis- $\omega$-alkenoyl-3(S)-amino-2-azetidinone precursors. Submitting the precursors to RCM, we faced an unexpected problem: cyclodimerization was the preferred outcome. This peculiar reactivity, explained by a computational study, led to unprecedented bis-azetidinyl-macrocycles acting as potent inhibitors of R39 D,D-carboxypeptidase, a bacterial model enzyme for PBPs.
\end{abstract}

๑) 2010 Elsevier Ltd. All rights reserved.

\section{Introduction}

Ring-closing metathesis (RCM) of $\alpha, \omega$-dienes is nowadays a very common reaction used for the construction of medium-sized and macrocyclic organic compounds. Its wide scope and use as the keystep in numerous total syntheses of complex target molecules have been reviewed ${ }^{1}$ recently. The thermodynamic and kinetic aspects of the RCM and related reactions catalyzed by ruthenium/carbene complexes have been discussed as well. ${ }^{2}$

Despite an increasing amount of technical reports, there are still no clear rules available for planning a new RCM synthesis: different catalysts and loading, different substrate concentrations, addition, and reaction times, different solvents, additives, and temperatures have to be tested for maximizing the yield of the desired cyclic product. Beside the experimental conditions, the ring size to be formed, the substrate structure, its substitution pattern, steric, and conformational factors will also influence the outcome of the reaction, i.e., the product $E / Z$ ratio, the formation of isomerized or/and oligomerized by-products. In general, oligomerization is considered detrimental to the RCM reaction ${ }^{2}$ and the corresponding products are neither isolated nor characterized. But in few cases, dimers, and in particular cyclic dimers, are highly desired products. $^{3}$ Recently, a double-centered catalyst has been designed to

\footnotetext{
* Corresponding author. Tel.: +32 104727 40; fax: +32 104741 68; e-mail address: jacqueline.marchand@uclouvain.be (J. Marchand-Brynaert).
}

favor the dimer ring-closing metathesis reaction ${ }^{4}$ and the competitive pathways leading to the cyclic monomer, and dimer have been theoretically studied with 1,7-octadiene as model substrate. ${ }^{5}$

We have previously applied the RCM reaction for the preparation of 1,3-bridged bicyclic $\beta$-lactams $\mathbf{A}$ (i.e., 2-azetidinones) derived from the commercial acetoxy-azetidinone used as the chiral precursor of carbapenem antibiotics ${ }^{6}$ (Fig. 1, Eq. (a)). Series of

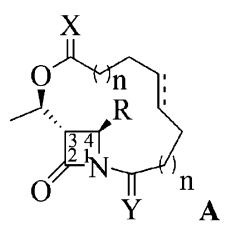

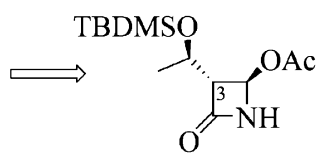

$\mathrm{R}=\mathrm{H}, \mathrm{n}-\mathrm{Pr}, \mathrm{OAc}$

$\mathrm{X}=\mathrm{Y}=\mathrm{O} ; \mathrm{X}=\mathrm{Y}=\mathrm{H}, \mathrm{H} ; \mathrm{X}=\mathrm{O}$ and $\mathrm{Y}=\mathrm{H}, \mathrm{H}$ TBDMS=tert-butyldimethylsilyl

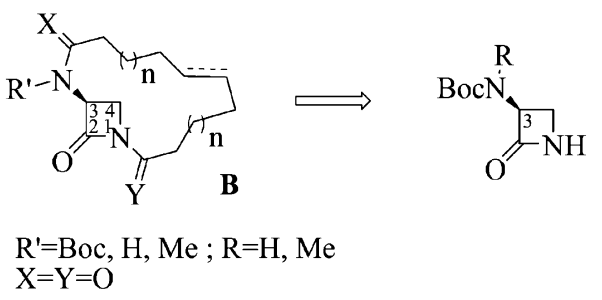


compounds featuring 12 and 13-membered rings (including $\mathrm{HC}=$ $\mathrm{CH}$ double bond or the reduced motif) have been obtained and evaluated as potential inhibitors of Penicillin Binding Proteins (PBPs). The weak activities recorded were attributed, among other factors, to the steric effect of the macrocycles, which hinders the socalled $\alpha$-face of the azetidinone ring and thus might prevent nucleophilic attack by the active serine of PBPs. This hypothesis derives from a theoretical investigation of the reactivity of the bridged azetidinones $\mathbf{A}$ when processed into a model of serine protease active site. ${ }^{6}$ To further our research on novel, non-traditional, bicyclic $\beta$-lactams, we have focused on 1,3-bridged compounds $\mathbf{B}$ derived from 3-amino-2-azetidinone featuring the amino substituent and the chirality of penicillins, and cephalosporins at the C(3) carbon (Fig. 1, Eq. (b)). This inversion of configuration regarding the carbapenem chiron (see Eq. (a)) should position the macrocycle above the $\beta$-face of the azetidinone ring and consequently make the serine nucleophilic attack easier on the $\alpha$-face during the processing of molecules $\mathbf{B}$ by PBPs.

In this article, we describe our synthetic efforts toward the target molecules $\mathbf{B}$ belonging to the bis-acylated family $(\mathrm{X}=\mathrm{Y}=\mathrm{O})$. From the 3-amino-2-azetidinone chiron, three series of RCM precursors have been prepared $\left(\mathrm{R}^{\prime}=\mathrm{Boc}, \mathrm{H}\right.$ or $\left.\mathrm{Me}\right)$ varying by the length of the $\omega$-alkenoyl chain fixed on the $\mathrm{N}(1)$ and $\mathrm{N}-\mathrm{C}(3)$ atoms. Surprisingly, under RCM conditions, the isolated products were all cases but one the cyclic dimers instead of the expected cyclic monomers B. These observations stimulated a theoretical investigation of the possible cyclization reactions. Our study highlights the dramatic effect of accessible conformations and flexibility of precursors on the intra- or intermolecular ring closure, particularly when the substrates possess amide, imide, and carbamate functions.

The inhibition potential of our compounds (precursors and RCM products) has been tested against R39 D,D-carboxypeptidase, which is a commonly used model for bacterial enzymes.

\section{Results and discussion}

\subsection{Synthesis}

The RCM reaction was chosen as the key-step for the synthesis of 1,3-bridged bicycles B, a strategy, which has already been successfully used for the preparation of 1,3-bridged derivatives $A .{ }^{6}$ The precursors are chiral azetidin-2-ones $C$ equipped with $\omega$-alkenoyl chains on the positions $\mathrm{N}(1)$ and $\mathrm{C}(3)-\mathrm{N}$ (Fig. 2). The starting chirons, i.e., (S)-3-(tertbutyloxycarbonyl)amino-2-azetidinone and (S)-3- $N$-methyl(tertbutyloxycarbonyl)amino-2-azetidinone, derived from commercially available Boc-L-serine and Boc-Me-L-serine, respectively.

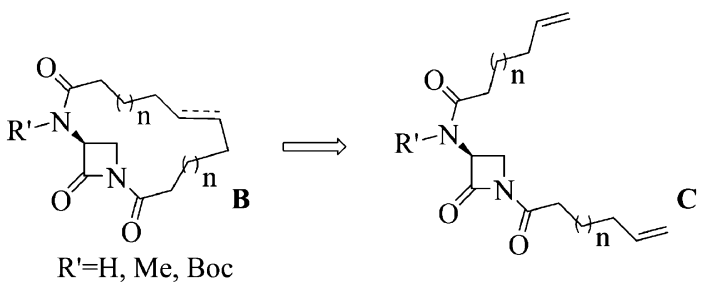

$$
\text { ¿ }
$$

Fig. 2. General RCM strategy.
Boc-L-serine $\mathbf{1}$ was converted, in nearly quantitative yield, into the corresponding hydroxamate 2, employing $O$-benzylhydroxylamine and DCC. ${ }^{7}$ Intramolecular cyclization was performed with the method proposed by Miller et al., ${ }^{7}$ in the presence of $\mathrm{PPh}_{3}$ and $\mathrm{CCl}_{4}$, and afforded the $\beta$-lactam 3 in $78 \%$ yield. Subsequent hydrogenation in the presence of Raney nickel ${ }^{8}$ gave the desired chiron $\mathbf{4}^{9}$ in quantitative yield (Scheme 1). In the first attempt to obtain the corresponding $\mathrm{N}-\mathrm{Me}$ chiron $\mathbf{8}$, we considered the direct methylation $^{10}$ of $\mathbf{3}$ into the desired intermediate $\mathbf{7}$. This reaction proceeded with $62 \%$ yield at the mmol scale, but the scaling-up was not successful. So we developed a similar route toward the N-Me derivatives as for the $\mathrm{N}-\mathrm{H}$ derivatives, starting from Boc-Me-L-serine 5. This compound was converted into hydroxamate $\mathbf{6}$ employing EDCI in $91 \%$ yield. The $\beta$-lactam 7 was obtained in $82 \%$ yield and subsequent hydrogenation afforded the chiron 8 in $64 \%$ yield.

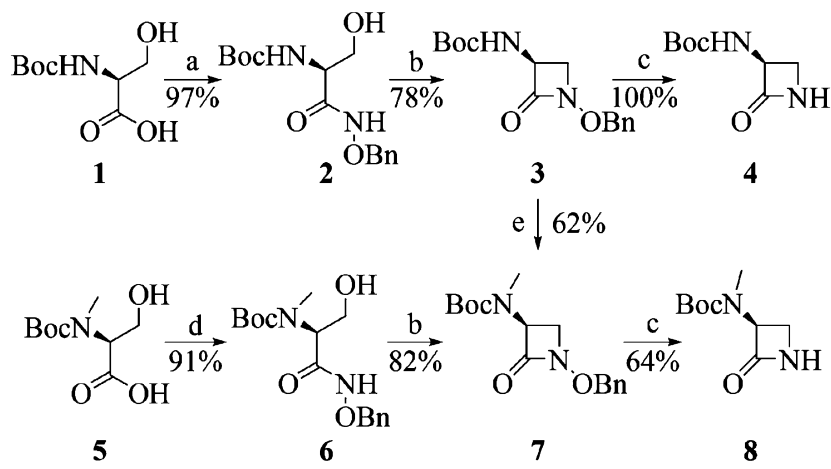

Scheme 1. Synthesis of chirons 4 and 8. Reagents and conditions: (a) DCC, $\mathrm{NH}_{2} \mathrm{OBn}$ THF, $0{ }^{\circ} \mathrm{C}$ to rt; (b) $\mathrm{PPh}_{3}, \mathrm{CCl}_{4}, \mathrm{TEA}, \mathrm{CH}_{3} \mathrm{CN}, 0{ }^{\circ} \mathrm{C}$ to rt; (c) $\mathrm{H}_{2}$, Raney-Ni, MeOH, rt; (d) EDCI, $\mathrm{NH}_{2} \mathrm{OBn}, \mathrm{CH}_{2} \mathrm{Cl}_{2}, 0{ }^{\circ} \mathrm{C}$ to rt; (e) $\mathrm{Me}_{2} \mathrm{SO}_{4}$, LiHMDS, THF, $-78{ }^{\circ} \mathrm{C}$ to rt.

The $\mathrm{N}$-Boc bis-acylated monocyclic azetidinones 9a-c were obtained in one step by treatment of the chiron 4 with 2 equiv of alkenoyl chlorides in the presence of 2 equiv of lithium hexamethyldisilazide (Scheme 2). 4-Butenoyl chloride $(n=0)$ is commercially available, while 5-hexenoyl chloride $(n=1)$ and 6-heptenoyl chloride $(n=2)$ have been previously synthesized starting from the corresponding commercial carboxylic acid. ${ }^{11}$

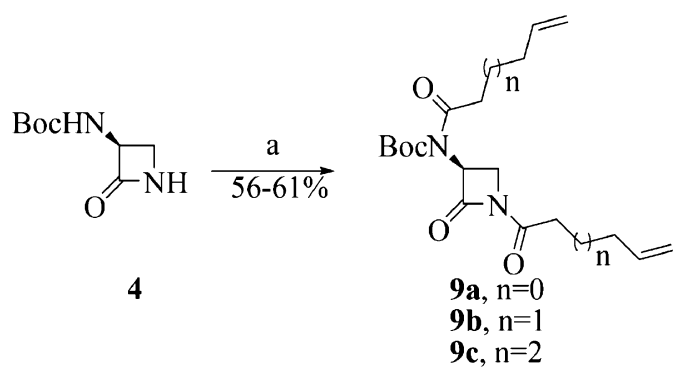

Scheme 2. Synthesis of bis-acylated $\mathbf{9}$. Reagents and conditions: (a) alkenoyl chloride LiHMDS, THF, $-78{ }^{\circ} \mathrm{C}$ to rt.

For the preparation of $\mathrm{N}-\mathrm{H}$ and $\mathrm{N}-\mathrm{Me}$ bis-acylated precursors, a three-step sequence was used (Scheme 3 ). The chiron $\mathbf{4}$ was mono-acylated at the $\mathrm{N}(1)$ position regioselectively under mild conditions giving the series of compounds $\mathbf{1 0 a}-\mathbf{c}$. Then, the Boc protecting group was removed with trifluoroacetic acid and the free amine function was acylated with the alkenoyl chlorides affording the series of compounds $\mathbf{1 2 a}-\mathbf{c}$. Similarly, the chiron 8 was mono-acylated (compounds 11a-c), $\mathrm{N}$-deprotected and acylated again to produce the $\mathrm{N}-\mathrm{Me}$ precursors $13 \mathbf{a}-\mathbf{c}$.

The first attempts at RCM were performed on bis-acylated compounds with $n=0$ (i.e., 9a, 12a, and 13a) with the view to form 12-membered macrocycles, under standard reaction conditions $\left(\mathrm{CH}_{2} \mathrm{Cl}_{2}, 40{ }^{\circ} \mathrm{C}, 5 \mathrm{mM}\right)$ in the presence of second generation Grubbs' 


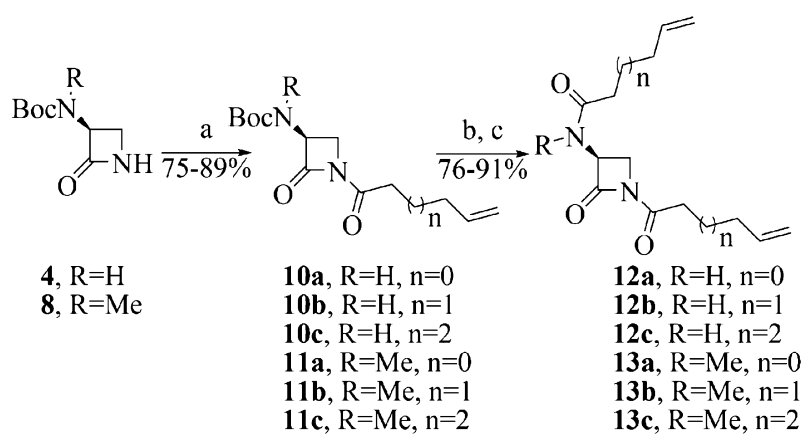

Scheme 3. Synthesis of bis-acylated 12, 13. Reagents and conditions: (a) alkenoyl chloride, pyridine, $\mathrm{CH}_{2} \mathrm{Cl}_{2}$, rt; (b) TFA, $\mathrm{CH}_{2} \mathrm{Cl}_{2}, 0{ }^{\circ} \mathrm{C}$ to rt; (c) alkenoyl chloride, TEA, $\mathrm{CH}_{2} \mathrm{Cl}_{2}, 0{ }^{\circ} \mathrm{C}$ to rt.

catalyst ( $5 \mathrm{~mol} \%$ ). Conversion was not observed in any case. To prevent the possible deactivation of the Ru-catalyst by the formation of a stable chelated alkylidene ring, we tried to use $\operatorname{Ti}\left(\mathrm{O}^{i} \operatorname{Pr}_{4}\right)^{12}$ as an additive, without success. Increasing the temperature (DCE, $\left.80^{\circ} \mathrm{C}\right)$, with or without $\mathrm{Ti}_{(}\left(\mathrm{O}^{i} \mathrm{Pr}_{4}\right)$, only led to the degradation of the starting material.

Next, RCM reactions were tested on compounds with $n=1$ (i.e., $9 \mathbf{b}$, 12b, and 13b) leading in principle to 14 -membered macrocycles, under the same standard conditions previously described. In each case, monitoring the reaction by TLC showed apparently the progressive formation of a single product over a time period of $24 \mathrm{~h}$. After several chromatographies, products were isolated with moderate yields (35-44\%). Products obtained from $\mathbf{9 b}, \mathbf{1 2 b}$, and $\mathbf{1 3 b}$ are named 15b, 16b, and 17b (Fig. 3), respectively. Their structural assignment proved to be an unexpectedly difficult problem: the ${ }^{1} \mathrm{H}$ and ${ }^{13} \mathrm{C}$ NMR

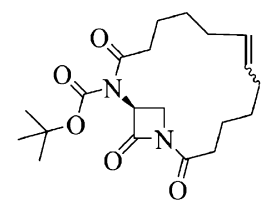

$14 c$
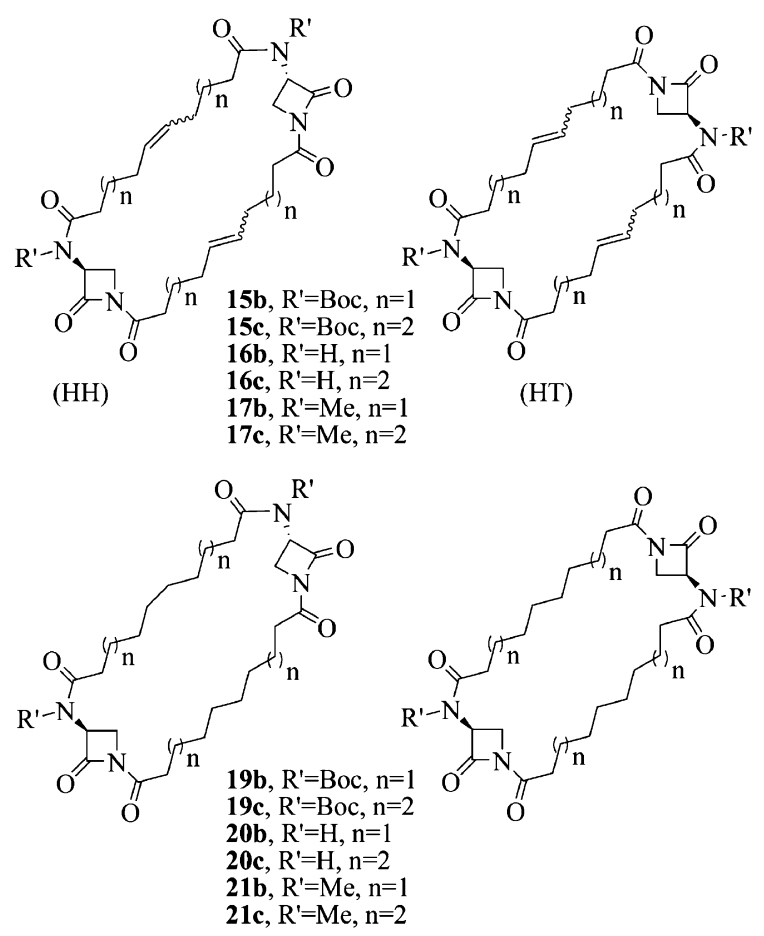

Fig. 3. Compounds synthesized by RCM. spectra were not well resolved, ${ }^{2}$ most probably due to the presence of several rotamers, stereoisomers (mixtures of $E / Z$ olefins), regioisomers (HH and HT dimers), and possible contamination by lower homologs (double bond migration and cyclization with the formal extrusion of one or two $\mathrm{CH}_{2}$ groups). The ${ }^{13} \mathrm{C}$ NMR spectra just showed the disappearance of the terminal olefin bonds and the preservation of the $\beta$-lactam ring, with the presence of the typical signals of $C(3)$ and $C(4)$ (Table 1 , entries 2,4 , and 6 ). In fact, mass spectrometry (MS) turned out to be the appropriate tool for accurate structural determination. Spectra were recorded in electrospray ionization (ESI) and atmospheric pressure chemical ionization (APCI) modes for comparison. All the isolated compounds were cyclic dimers, most probably a mixture of head-head (HH) and head-tail(HT) isomers, as drawn in the Fig. 3. ESI is a soft ionization method but well-known to favor the formation of dimeric adducts during the evaporation step. Moreover, ionization by formation of $\mathrm{Na}^{+}$or $\mathrm{K}^{+}$adducts is also frequently observed. These adducts can be monomeric or dimeric. In our case, as observed during the analysis of the bis-acylated precursors, formation of dimeric $\mathrm{Na}^{+}$adducts was the major ionization process in ESI. So for the compounds issued of the RCM, we could not be sure that we really observe a cyclodimer compound in complex with $\mathrm{Na}^{+}$or two cyclomonomer compounds in complex with $\mathrm{Na}^{+}$. To confirm, we applied a somewhat harder method of ionization, APCI not known to favor formation of adducts, which showed that the compounds are really the cyclodimers (Table 1 ). Moreover, the analysis of the ESI spectra allowed us to detect the presence, in relatively weak abundance, of lower homologs (double bond migration and cyclization with the formal extrusion of one $\mathrm{CH}_{2}$ group).

The RCM reactions were finally tested on compounds with $n=2$ (i.e., 9c, 12c, and 13c) in the same standard conditions as previously. 16-Membered cyclomonomers are expected, but as previously for compounds with $n=1$, the reactions afforded the cyclodimers $15 \mathbf{c}$, 16c, and 17c, respectively, in modest yields (10-30\%) (Table 1 and Fig. 3). Surprisingly, in one case (starting material 9c), the macrocyclic monomer 14c was also obtained (Table 1 and Fig. 3), but in low yield (9\%).

The monomer 14c and the series of cyclodimers $15 b, \mathbf{c}, 16 \mathbf{b}, \mathbf{c}$ and $\mathbf{1 7 b}, \mathbf{c}$ were subjected to catalytic hydrogenation to produce the corresponding saturated macrocycles $18 \mathbf{c}$ and 19b, c, 20b, c, and 21b, c, respectively (Fig. 3).

Bis-acylated precursors with $n=0$ did not cyclize at all: neither the cyclomonomers nor the cyclodimers could be detected. Bis-acylated precursors with $n=1$ gave cyclodimers but did not cyclize into the monomers, therefore we suspected that the length of the carbon chain bearing the olefin was too short to afford the 14-sized macrocycle. On the other hand, the formation of compound 14c, proves that the chain length is long enough to produce the 16-sized cyclic product, even if the dimerization remains the preferred process. We set out to find reaction conditions to promote the formation of cyclomonomer derived from 12c $(n=2)$. There are numerous parameters that could influence the outcome of the RCM, and there are no pre-established conditions, which would guarantee the successful production of a desired compound. We have tested several parameters, such as the choice of the catalyst, the solvent, the temperature, the concentration, and the reaction time. ${ }^{2}$

First and second generation Grubbs or Hoveyda-Grubbs, and Neolyst M2 catalysts were tested but in all cases, they only afforded the cyclodimer 20c $(n=2)$. Carrying out the RCM reactions at rt also produced the cyclodimer. It is known that increasing the reaction temperature can control the product distribution (monomer vs dimer) in RCM macrocyclization. ${ }^{13}$ But in our case, the RCM reaction in refluxing DCE afforded only the cyclodimer, just faster than at rt. Decreasing the concentration of the reaction, from $5 \mathrm{mM}$ to $1 \mathrm{mM}$, or using the 'infinite dilution' conditions ${ }^{14}$ led to a lower yield of the cyclodimer; the desired cyclomonomer was never detected. The results of these various attempts seem to point toward intrinsic 
Table 1

Selected structural data of cyclic dimers and monomer

\begin{tabular}{|c|c|c|c|c|c|}
\hline Entry & Compound & ${ }^{13} \mathrm{C} \mathrm{C}_{4} ; \mathrm{C}_{3} ; \mathrm{C}=\mathrm{C}(\mathrm{ppm})$ & MS ESI $m / z$ Relative abundance & MS APCI $m / z[\mathrm{M}+\mathrm{H}]^{+}$ & Isolated yield ${ }^{\mathrm{a}}(\%)$ \\
\hline 1 & $14 \mathrm{c}$ & $\begin{array}{l}44.6 \\
59.7 \\
130.6 \text { and } 131.1\end{array}$ & $\begin{array}{l}401(69)[\mathrm{M}+\mathrm{Na}]^{+} \\
301(100)\left(401-\mathrm{CO}_{2} \text { and } \mathrm{C}_{4} \mathrm{H}_{8}\right)\end{array}$ & $\begin{array}{l}379.22275 \\
\left(\mathrm{C}_{20} \mathrm{H}_{31} \mathrm{O}_{5} \mathrm{~N}_{2}\right)\end{array}$ & $9^{\mathrm{b}}$ \\
\hline 2 & $15 b$ & $\begin{array}{l}43.7-43.8 \\
57.5-57.8 \\
129.9-130.2-130.5-131.6\end{array}$ & $\begin{array}{l}723(100)[\mathrm{M}+\mathrm{Na}]^{+} \\
709(13)\left(723-\mathrm{CH}_{2}\right) \\
623(48)\left(723-\mathrm{CO}_{2} \text { and } \mathrm{C}_{4} \mathrm{H}_{8}\right) \\
523(68)\left(723-2\left(\mathrm{CO}_{2} \text { and } \mathrm{C}_{4} \mathrm{H}_{8}\right)\right.\end{array}$ & $\begin{array}{l}701.37449 \\
\left(\mathrm{C}_{36} \mathrm{H}_{53} \mathrm{O}_{10} \mathrm{~N}_{4}\right)\end{array}$ & 44 \\
\hline 3 & $15 c$ & $\begin{array}{l}43.8-43.9 \\
57.2-57.4 \\
130.3-130.5-130.6-130.7\end{array}$ & $\begin{array}{l}779(100)[\mathrm{M}+\mathrm{Na}]^{+} \\
765(10)\left(779-\mathrm{CH}_{2}\right) \\
679(37)\left(779-\mathrm{CO}_{2} \text { and } \mathrm{C}_{4} \mathrm{H}_{8}\right) \\
579(33)\left(779-2\left(\mathrm{CO}_{2} \text { and } \mathrm{C}_{4} \mathrm{H}_{8}\right)\right)\end{array}$ & $\begin{array}{l}757.43682 \\
\left(\mathrm{C}_{40} \mathrm{H}_{61} \mathrm{O}_{10} \mathrm{~N}_{4}\right)\end{array}$ & $10^{\mathrm{b}}$ \\
\hline 4 & $16 b$ & $\begin{array}{l}46.0 \\
55.7 \\
130.8-131.5\end{array}$ & $\begin{array}{l}523(100)[\mathrm{M}+\mathrm{Na}]^{+} \\
509(11)\left(523-\mathrm{CH}_{2}\right)\end{array}$ & $\begin{array}{l}501.26999 \\
\left(\mathrm{C}_{26} \mathrm{H}_{37} \mathrm{O}_{6} \mathrm{~N}_{4}\right)\end{array}$ & 35 \\
\hline 5 & $16 c$ & $\begin{array}{l}45.1-45.4 \\
55.2-55.6 \\
130.0-130.6-130.8-130.9\end{array}$ & $\begin{array}{l}579(100)[\mathrm{M}+\mathrm{Na}]^{+} \\
565(35)\left(579-\mathrm{CH}_{2}\right) \\
551(7)\left(579-\mathrm{C}_{2} \mathrm{H}_{4}\right)\end{array}$ & $\begin{array}{l}557.33287 \\
\left(\mathrm{C}_{30} \mathrm{H}_{45} \mathrm{O}_{6} \mathrm{~N}_{4}\right)\end{array}$ & 28 \\
\hline 6 & 17b & $\begin{array}{l}43.1 \\
61.8-63.0 \\
130.4-130.7-131.0-131.4\end{array}$ & $\begin{array}{l}551(100)[\mathrm{M}+\mathrm{Na}]^{+} \\
537(14)\left(551-\mathrm{CH}_{2}\right)\end{array}$ & $\begin{array}{l}529.30170 \\
\left(\mathrm{C}_{28} \mathrm{H}_{41} \mathrm{O}_{6} \mathrm{~N}_{4}\right)\end{array}$ & 43 \\
\hline 7 & 17c & $\begin{array}{l}43.1-43.2 \\
62.5-63.1 \\
130.2-130.4-130.5-130.6\end{array}$ & $\begin{array}{l}607(100)[\mathrm{M}+\mathrm{Na}]^{+} \\
593(38)\left(607-\mathrm{CH}_{2}\right)\end{array}$ & $\begin{array}{l}585.36407 \\
\left(\mathrm{C}_{32} \mathrm{H}_{49} \mathrm{O}_{6} \mathrm{~N}_{4}\right)\end{array}$ & 40 \\
\hline
\end{tabular}

${ }^{a}$ Conversion (80-90\%). Crude yields (50-60\%). Analysis of crude mixtures by TLC, MS, and NMR: oligomers, isomerized starting materials, and $\beta$-lactam degradation compounds were observed as side-products. Several column chromatographies are necessary to clear out the catalyst.

${ }^{b}$ Very low isolated yields because major fraction is a mixture of $\mathbf{1 4 c}$ and $\mathbf{1 5 c}$.

structural parameters governing the outcome of our RCM reactions. In the next section we describe ab initio calculations that explain our results.

\subsection{Computational chemistry}

The almost exclusive formation of macrocyclic dimers instead of cyclic monomers under RCM conditions is rarely mentioned in previous literature and thus deserves to be examined from the theoretical point of view.

The geometry of all the molecules has been fully optimized at the B3LYP level using 6-31G basis set with added polarization functions. ${ }^{15}$ All the calculations have been performed with the Gaussian 03 program. ${ }^{16}$ For the Grubbs adducts, the basis sets LanL2MB and Lan2DZ, minimal and double $\zeta$ functions for the first row and Los Alamos effective core potential on the other atoms, have been used with the same B3LYP functional. ${ }^{17}$

The precursors have been studied (bis-acylated azetidinones 9 $(\mathrm{N}$-Boc), $12(\mathrm{~N}-\mathrm{H})$, and $\mathbf{1 3}(\mathrm{N}-\mathrm{Me}))$ taking into account several factors, which could have an incidence on the formation of the cyclic monomer (see Supplementary data): the tautomeric amide forms, the cis or trans geometry of the amide functions, the conformations of the $\omega$-alkenoyl chains leading to a cycle located up or down with respect to the $\beta$-lactam plane in a range of $5-10 \mathrm{kcal} /$ mol. In all cases, the $\mathrm{OH}$-tautomers are less stable than the standard amide in a range of $10-20 \mathrm{kcal} / \mathrm{mol}$. In the same way, the trans amide and the conformation anti of the two carbonyls of the imide are preferred. The syn and anti conformations are, respectively, noted $i$ and ii (Fig. 4 and Table 2). The conformational space is strongly influenced by the interaction between the two imide carbonyls. which tend to move off.

The trans/cis rotation barrier depends on the substituent of the amide nitrogen. The decreasing values going from $\mathrm{N}-\mathrm{H}, \mathrm{N}-\mathrm{Me}$ and $\mathrm{N}$-Boc are $20.49,16.86$, and $3.50 \mathrm{kcal} / \mathrm{mol}$. A great number of minima could be localized in a large energy range $(20 \mathrm{kcal} / \mathrm{mol})$. The ring size also has an incidence on the conformation related to the number of $\mathrm{CH}_{2}$ on both sides of the double bond. In order to sweep a common conformational space for all the substituted molecules $\mathbf{9 , 1 2}$, and $\mathbf{1 3}$, four conformations (amide cis or trans; imide carbonyls in conformation i or ii) have been searched and located. In the case of
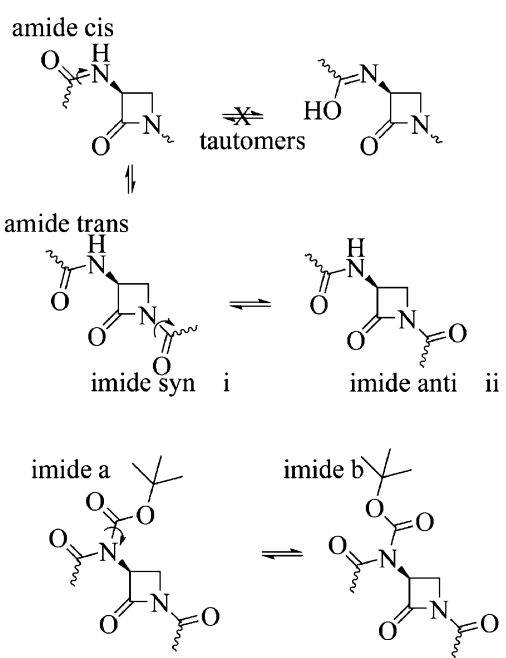

Fig. 4. Degrees of rotation.

the $N$-Boc substitution, an additional degree of freedom has to be taken into account: the conformation with the two Boc carbonyls syn and anti noted a and b (Fig. 4 and Table 2). Last, several conformations of the 14 - and 16 -membered rings under the $\beta$-lactam plane have been located. They are less stable than the up conformations (i.e., above the $\beta$-lactam plane) with a mean energy difference of $4 \mathrm{kcal} / \mathrm{mol}$ for $\mathbf{9 c}$ and $10 \mathrm{kcal} / \mathrm{mol}$ for the $\mathbf{9 b}$.

The heats of formation of the cyclic monomers have been calculated with respect to the parent conformation of the open precursor: all the values are positive (Table 2). Fig. 5 summarizes, on the same graph, for the compound $\mathbf{1 4 c}(n=2)$ the relative energies of the precursor $\mathbf{9 c / c y c l i c}$ monomer in the selected conformations and also the respective heat of formation. Most of the time, the amide trans conformations are the most stable ones. Fig. 6 illustrates the conformational diversity for compound $\mathbf{1 4} \mathbf{c}$ with 4 conformers represented. It can be noted that the heat of formation of the $N$-Boc substituted molecules is higher for the 12-membered ring (9a precursor) than for the 14- and 16-membered rings ( $\mathbf{9 b}$ and $\mathbf{9 c}$ precursors).

In order to investigate the incidence of the conformations on the cycle formation, the two possible intermediates of the Grubbs 
Table 2

Relative energies of the precursors/cyclic monomers in the selected conformations and also the respective heat of formation resulting from the cyclization of the $\mathbf{9}$ ( $\mathrm{N}$-Boc), $12(\mathrm{~N}-\mathrm{H})$, and $13(\mathrm{~N}-\mathrm{Me})$ precursors

\begin{tabular}{|c|c|c|c|c|c|c|c|}
\hline \multirow[t]{2}{*}{ Precursor } & \multirow[t]{2}{*}{ Geometry } & \multicolumn{2}{|c|}{$\begin{array}{l}\text { Relative energy of open } \\
\text { precursors }(\mathrm{kcal} / \mathrm{mol})\end{array}$} & \multicolumn{2}{|c|}{$\begin{array}{l}\text { Relative energy of monomers } \\
(\mathrm{kcal} / \mathrm{mol})\end{array}$} & \multicolumn{2}{|c|}{$\begin{array}{l}\text { Heat of formation of } \\
\text { monomers }(\mathrm{kcal} / \mathrm{mol})\end{array}$} \\
\hline & & $i$ & ii & $i$ & $i i$ & $i$ & $i i$ \\
\hline \multirow[t]{2}{*}{$12 a$} & Amide cis & 10.21 & 4.94 & 4.19 & 0.00 & 8.63 & 9.71 \\
\hline & Amide trans & 5.18 & 0.00 & 9.17 & 0.89 & 18.65 & 15.54 \\
\hline \multirow[t]{2}{*}{$12 b$} & Amide cis & 10.33 & 4.77 & 4.95 & 7.12 & 7.47 & 15.20 \\
\hline & Amide trans & 5.95 & 0.00 & 5.56 & 0.00 & 12.45 & 12.85 \\
\hline \multirow[t]{2}{*}{$12 c$} & Amide cis & 10.22 & 4.77 & 10.26 & 1.88 & 8.53 & 5.56 \\
\hline & Amide trans & 4.88 & 0.00 & 5.00 & 0.00 & 8.57 & 8.45 \\
\hline \multirow[t]{2}{*}{ 13a } & Amide cis & 8.16 & 2.84 & 18.58 & 0.00 & 22.55 & 9.29 \\
\hline & Amide trans & 6.03 & 0.00 & 9.80 & 4.30 & 15.90 & 16.43 \\
\hline \multirow[t]{2}{*}{$13 \mathbf{b}$} & Amide cis & 8.59 & 3.01 & 6.67 & 0.00 & 7.26 & 6.17 \\
\hline & Amide trans & 6.53 & 0.00 & 9.45 & 2.97 & 12.09 & 12.15 \\
\hline \multirow[t]{2}{*}{$13 c$} & Amide cis & 0.00 & 6.47 & 8.68 & 0.21 & 20.70 & 5.78 \\
\hline & Amide trans & 9.05 & 3.66 & 5.35 & 0.00 & 8.32 & 8.36 \\
\hline \multirow[t]{2}{*}{ 9a } & Amide cis a & 17.09 & 11.80 & 0.99 & 9.53 & 0.21 & 14.03 \\
\hline & Amide cis b & 13.63 & 8.46 & 2.89 & 6.18 & 5.57 & 14.02 \\
\hline \multirow[t]{2}{*}{ 9a } & Amide trans a & 6.19 & 0.88 & 3.77 & 0.99 & 13.89 & 16.42 \\
\hline & Amide trans b & 6.75 & 0.00 & 3.83 & 0.00 & 13.39 & 16.31 \\
\hline \multirow[t]{2}{*}{$9 b$} & Amide cis a & 8.45 & 3.56 & 11.38 & 2.99 & 6.47 & 2.96 \\
\hline & Amide cis b & 5.04 & 0.26 & 8.12 & 11.23 & 6.61 & 14.50 \\
\hline \multirow[t]{2}{*}{$9 b$} & Amide trans a & 5.51 & 0.45 & 6.93 & 0.50 & 4.96 & 3.59 \\
\hline & Amide trans b & 5.96 & 0.00 & 6.30 & 0.00 & 3.87 & 3.53 \\
\hline \multirow[t]{2}{*}{$9 c^{a}$} & Amide cis a & 15.32 & 10.81 & 15.73 & 8.17 & 8.16 & 5.11 \\
\hline & Amide cis b & 11.96 & 7.54 & 12.40 & 4.92 & 8.20 & 5.13 \\
\hline \multirow[t]{2}{*}{$9 c^{a}$} & Amide trans a & 5.54 & 1.02 & 5.46 & 0.42 & 7.67 & 7.15 \\
\hline & Amide trans b & 5.03 & 0.00 & 5.03 & 0.00 & 7.75 & 7.75 \\
\hline
\end{tabular}

a Led to compound 14c.

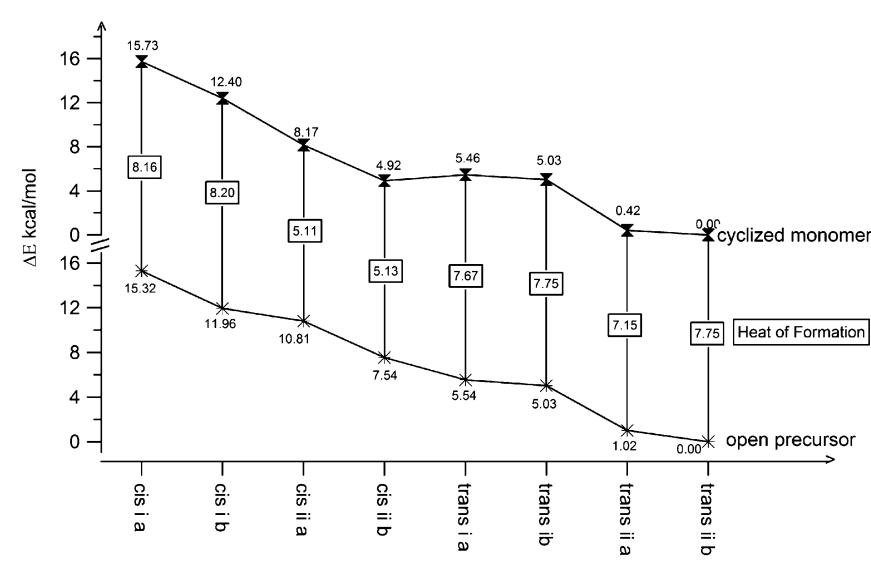

Fig. 5. Relative energies of precursor/cyclic monomer in the selected conformations and heats of formation for $\mathbf{1 4 c}$.

catalyst first step addition have been computed for $\mathbf{9 c}, \mathbf{1 2 c}, \mathbf{9 b}$, and 12b (see Supplementary data). In $\mathrm{N}-\mathrm{H}$ series, some adducts generated with both functions amide and imide in the cis or trans conformation have a favorable orientation for the ring closing into monomer. But, only the cis amide conformation allows the introduction of the $\mathrm{N}$-Boc substituent due to steric hindrance. This spatial orientation, which is constrained by the $\mathrm{N}$-Boc substituent can be related to the appearance of $\mathbf{1 4} \mathbf{c}$ as RCM monomer product along with the dimers. Fig. 7 illustrates the optimized geometry of the $\mathbf{9 c}$ adduct with the $\mathrm{N}-\mathrm{C}(3)$-arm linked to the Ru atom.

In order to explain the preferential formation of dimers, the search of different conformations has been investigated. For the three sizes of the ring, two conformations of the $\beta$-lactam can be located giving rise to a head-head ( $\mathrm{HH})$ or head-tail (HT) arrangement in the macrocycle (see Fig. 3). Moreover, an additional factor has to be considered, mainly for the $\mathrm{N}-\mathrm{H}$ substitution, due to the formation of intramolecular $\mathrm{H}$ bonds, which significantly stabilize some conformations. Again, with the conformation cis/trans of the amide and syn/ anti imide orientation, a lot of conformations have been found, which
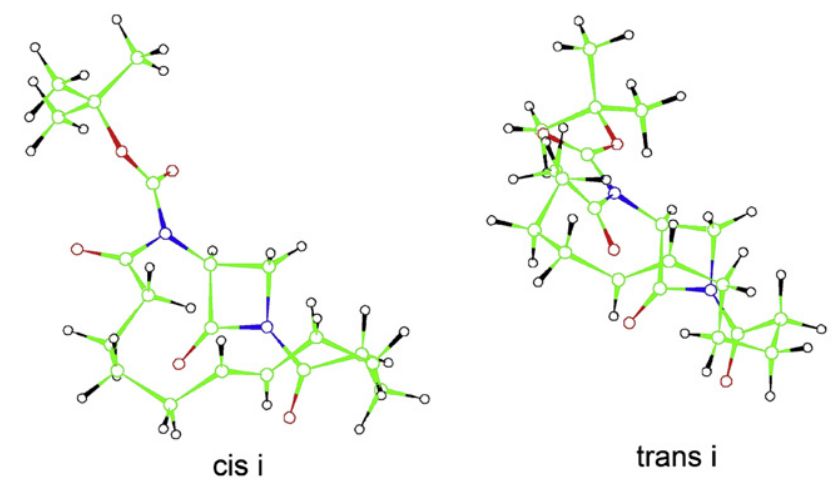

trans $\mathrm{i}$

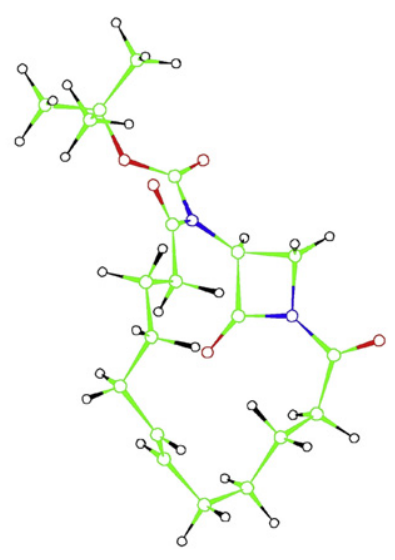

cis ii

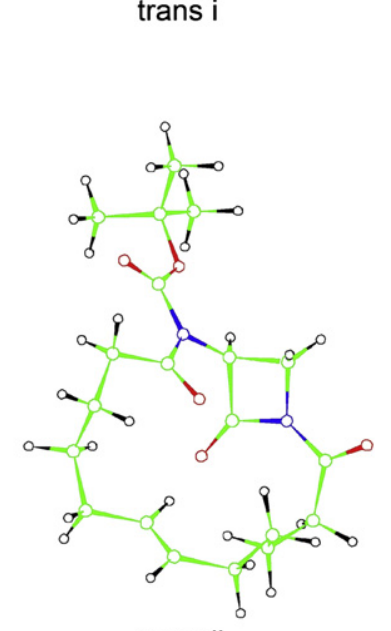

trans ii
Fig. 6. Four conformers of compound $\mathbf{1 4 c}$, in geometry b.

are not necessarily geometrically related going from $\mathrm{N}-\mathrm{H}$ to $\mathrm{N}$-Boc substitutions. As an example, Fig. 8 illustrates the most stable conformer of compounds $15 \mathrm{c}(\mathrm{HT})$ and $\mathbf{1 6 c}(\mathrm{HH})$.

The energy range is large and superior to $20 \mathrm{kcal} / \mathrm{mol}$. In most of the cases, the trans conformation of the two amides is more stable 


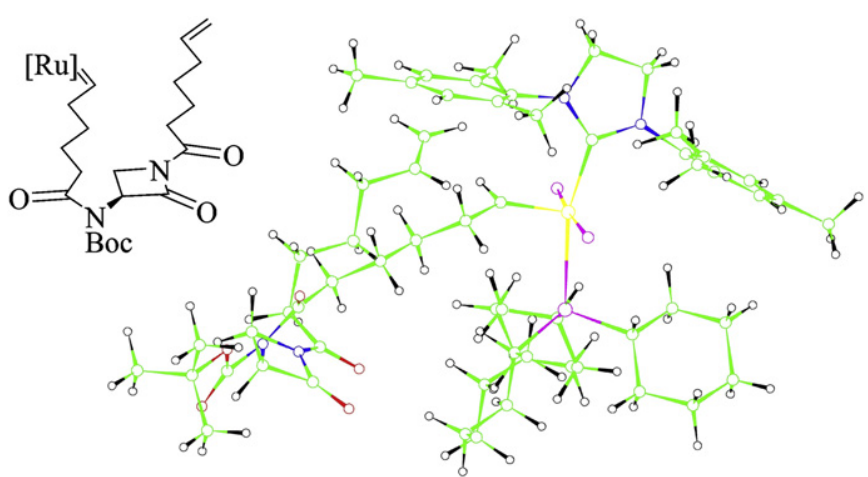

Fig. 7. Optimized geometry of the $\mathbf{9 c}$ adduct.
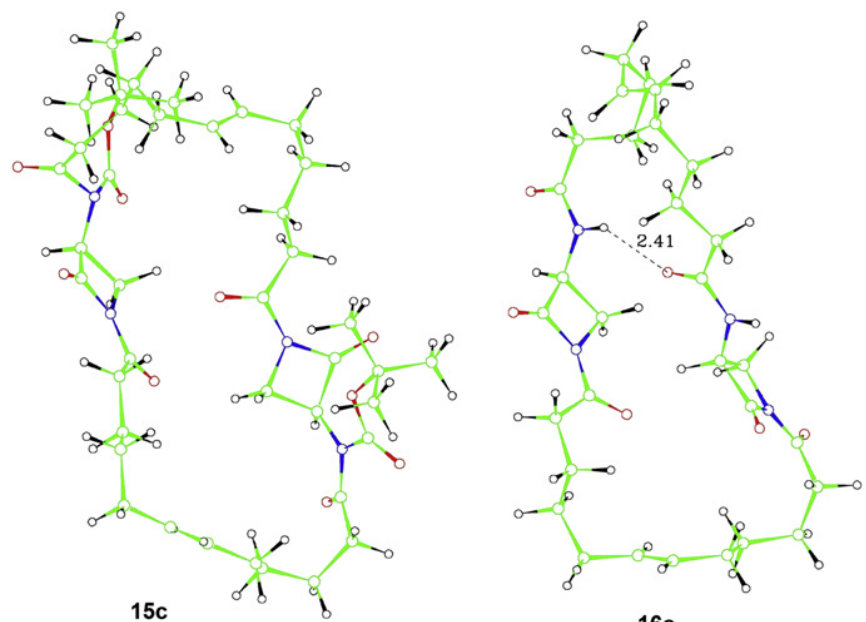

$16 c$

Fig. 8. Most stable conformer of compounds $\mathbf{1 5 c}(\mathrm{HT})$ and $\mathbf{1 6 c}(\mathrm{HH})$.

than other combinations cis/trans or cis/cis. For this spatial disposition, a complete homogenous set of conformers has been located. Most of the time, the HT conformers are more stable than the HH ones. As for the monomers, the heat of formation has been calculated with respect to the open precursor (Table 3 ). In many cases, the heat of formation of dimer is negative or slightly positive with an energy demand lower than the one required for the cyclic monomer formation (see Table 2). Remarkably, the heat of formation of 15c corresponds to the highest positive value $(9.13 \mathrm{kcal} / \mathrm{mol})$ of the selected conformers, higher than the one of the cyclic monomer $\mathbf{1 4 c}$, which is experimentally also observed $(7.75 \mathrm{kcal} / \mathrm{mol})$.

Table 3

Heat of formation of macrocyclic dimers for selected compounds

\begin{tabular}{llcl}
\hline Precursor & Product & $\Delta \mathrm{E}(\mathrm{HH}-\mathrm{HT})(\mathrm{kcal} / \mathrm{mol})$ & Heat of formation $(\mathrm{kcal} / \mathrm{mol})$ \\
\hline $\mathbf{1 2 a}$ & - & 2.23 & -1.11 \\
$\mathbf{1 3 a}$ & - & 4.09 & 1.75 \\
$\mathbf{9 a}$ & - & 10.37 & 6.55 \\
$\mathbf{1 2 b}$ & $\mathbf{1 6 b}$ & 9.59 & -5.66 \\
$\mathbf{1 3 b}$ & $\mathbf{1 7 b}$ & -1.13 & 3.76 \\
$\mathbf{9 b}$ & $\mathbf{1 5 b}$ & -1.74 & -8.06 \\
$\mathbf{1 2 c}$ & $\mathbf{1 6 c}$ & -2.43 & -1.81 \\
$\mathbf{1 3 c}$ & $\mathbf{1 7 c}$ & 3.09 & 4.99 \\
$\mathbf{9 c}$ & $\mathbf{1 5 c}$ & 5.35 & 9.13 \\
\hline
\end{tabular}

\subsection{Inhibition of R39 D,D-carboxypeptidase}

All bis-acylated compounds, precursors, and cyclic products, were tested against Actinomadura R39, ${ }^{18}$ a model serine-enzyme of low molecular weight D,D-carboxypeptidases, usually considered for a preliminary screening of penicillin-like compounds. R39 and the tested azetidinones $(100 \mu \mathrm{M})$ were incubated $\left(1 \mathrm{~h}, 25^{\circ} \mathrm{C}\right)$ together. After preincubation, the residual activity (RA) was determined by observing the hydrolysis of the thiolester substrate, ${ }^{19}$ in the presence of DTNB (a fluoresceine-labeled ampicillin ${ }^{20}$ ), catalyzed by the non-inhibited enzyme. Thus, in this protocol, our compounds do acylate R39, and the RA is determined by the amount of covalent R39-ampicillin complexes formed, measured by fluorescence spectroscopy. The results are given in Table 4 as percentages (\%) of initial activity. Low values indicate very active compounds as the bacterial enzyme has been inhibited by the tested compound and consequently cannot hydrolyze its reporter substrate. A tested compound is considered as a 'hit' (i.e., potential inhibitor) for a $\mathrm{RA}<80 \%$.

Table 4

Evaluation of azetidinones against R39 D,D-carboxypeptidase

\begin{tabular}{llllll}
\hline Entry & Compound & RA (\%) & Entry & Compound & RA (\%) \\
\hline 1 & $\mathbf{9 a}$ & $82 \pm 5$ & 13 & $\mathbf{1 5 c}$ & $4 \pm 3$ \\
2 & $\mathbf{9 b}$ & $87 \pm 1$ & 14 & $\mathbf{1 6 b}$ & $4 \pm 8$ \\
3 & $\mathbf{9 c}$ & $96 \pm 3$ & 15 & $\mathbf{1 6 c}$ & 0 \\
4 & $\mathbf{1 2 a}$ & $>100$ & 16 & $\mathbf{1 7 b}$ & $93 \pm 5$ \\
5 & $\mathbf{1 2 b}$ & $17 \pm 9$ & 17 & $\mathbf{1 7 c}$ & $43 \pm 3$ \\
6 & $\mathbf{1 2 c}$ & $23 \pm 0$ & 18 & $\mathbf{1 9 b}$ & $101 \pm 8$ \\
7 & $\mathbf{1 3 a}$ & $>100$ & 19 & $\mathbf{1 9 c}$ & $103 \pm 5$ \\
8 & $\mathbf{1 3 b}$ & $103 \pm 3$ & 20 & $\mathbf{2 0 b}$ & 2 \\
9 & $\mathbf{1 3 c}$ & $95 \pm 7$ & 21 & $\mathbf{2 0 c}$ & 0 \\
10 & $\mathbf{1 4 c}$ & 0 & 22 & $\mathbf{2 1 b}$ & $88 \pm 7$ \\
11 & $\mathbf{1 8 c}$ & $14 \pm 10$ & 23 & $\mathbf{2 1 c}$ & $39 \pm 0$ \\
12 & $\mathbf{1 5 b}$ & $111 \pm 2$ & 24 & $\mathbf{P e n G}$ & $0^{21}$ \\
\hline
\end{tabular}

Amongst the precursors (non-cyclized compounds: Table 2, entries 1-9), two molecules are good inhibitors of R39, namely $\mathbf{1 2 b}$ and 12c ( $\mathrm{N}-\mathrm{H}$ family, entries $5-6)$. The cyclomonomers $14 \mathrm{c} / \mathbf{1 8 c}$ (entries 10-11) also inhibited efficiently R39 despite the fact that the molecules are still $N$-Boc protected. Unfortunately, the corresponding $\mathrm{N}-\mathrm{H}$ derivatives were not accessible for testing because the TFA treatment of $\mathbf{1 4 c}$ and $\mathbf{1 8 c}$ (for Boc cleavage) gave a mixture of deprotected $\beta$-lactams and hydrolyzed products. Surprisingly, the cyclodimers (entries 12-23) are generally more active than their respective precursors and some of them showed very good inhibition potential, i.e., 16b, c (entries 14,15), and 20b, c (entries 20-21); these correspond to the $\mathrm{N}-\mathrm{H}$ (deprotected) derivatives. It is worth noting that all these non-traditional inhibitors are quite lipophilic compounds, devoid of the carboxylic function usually found in penicillins and related antibiotics.

\section{Conclusion}

The RCM reaction applied to azetidinone substrates featuring amide and imide functions led almost exclusively to macrocyclic dimers instead of the cyclomonomers. These unexpected results are in fact in good agreement with the computed heats of formation of the dimers and monomers, respectively. Our theoretical investigation has highlighted the dramatic importance of the conformational flexibility of the substrates and products on the RCM reaction. Interestingly, in the only case where the dimer (i.e., 15c) was predicted to be slightly less favored than the corresponding monomer (i.e., 14c), both products were experimentally observed.

The biological activity results collected with our compounds using the R39 serine-enzyme are promising. The novel bicyclic $\beta$-lactams $\mathbf{1 4 c}$ and $\mathbf{1 8 c}$ are good inhibitors of this D,D-peptidase while their precursor $\mathbf{9 c}$ is not active. Also, the bis-azetidinyl-macrocycles $15 c, 16 b, 16 c, 20 b$, and $20 c$ have shown remarkable inhibitory effect.

Since the azetidinone moieties are not activated by the traditional angular strain leading to 'twisted' amide functions like in penicillins, ${ }^{22}$ the activity should be attributed, amongst other 
factors, to the flexibility of the substrates (a lot of conformers are possible) allowing their adjustment into the enzymic pocket and their easy conformational rearrangement during the processing by the active site serine residue. Moreover, the most active compounds are those with $\mathrm{R}^{\prime}=\mathrm{H}(\mathbf{1 6 b}, \mathbf{c}, \mathbf{2 0 b}, \mathbf{c})$ comparatively to the corresponding $N$-substituted derivatives with $\mathrm{R}^{\prime}=\mathrm{Me}(\mathbf{1 7 b}, \mathbf{c}, \mathbf{2 1 b}, \mathbf{c})$ and $\mathrm{R}^{\prime}=\operatorname{Boc}(\mathbf{1 5 b}, \mathbf{1 9 b}, \mathbf{c})$, most probably for steric reasons, and the activity does not seem to be so much dependent on the preferred head-tail or head-head dimeric structures.

Work is in progress for producing preferably bicyclic azetidinones related to the structures $\mathbf{1 4 c / 1 8 c}$, i.e., cyclomonomers. In case of difficult macrocyclizations, a novel auxiliary has been recently developed as conformational control element (CCE) favoring the appropriate conformation toward the desired RCM reaction. ${ }^{23}$ Since this elegant strategy is not readily applicable to our precursors $\mathbf{9 , 1 2}$, and 13, we are now investigating the corresponding bis-alkylated derivatives, which show an increase of the freedom degrees for the side-chains rotations.

\section{Experimental section}

\subsection{General considerations}

Experiments were performed under argon atmosphere in flame-dried glassware. All solvents, including anhydrous solvents, and reagents were purchased from Acros Organics, Alfa Aesar, Fluka, Sigma-Aldrich or VWR, and used without any further purification. TLC analyses were performed on aluminum plates coated with silica gel $60 \mathrm{~F}_{254}$ (Merck) and visualized with a $\mathrm{KMnO}_{4}$ solution and UV (254 nm) detection, and flash column chromatography was performed on silica gel (40-60 mesh) purchased from Rocc. Melting points (mp) were determined on a Büchi B-540 apparatus calibrated with caffeine, vanillin, and phenacetin. $[\alpha]_{D}$ was measured on Perkin-Elmer 241MCpolarimeter, at $20{ }^{\circ} \mathrm{C}$, in $\mathrm{CHCl}_{3}$. Concentrations are given in percentage $(\mathrm{g} / 100 \mathrm{~mL})$. Nuclear magnetic resonance $\left({ }^{1} \mathrm{H}\right.$ and $\left.{ }^{13} \mathrm{C}\right)$ spectra were recorded at $300 \mathrm{MHz}$ for proton and $75 \mathrm{MHz}$ for carbon (Bruker Avance 300) or $500 \mathrm{MHz}$ for proton and $125 \mathrm{MHz}$ for carbon (Bruker Avance 500) using deuterated chloroform $\left(\mathrm{CDCl}_{3}\right)$ or deuterated methanol $\left(\mathrm{CD}_{3} \mathrm{OD}\right)$. Chemical shifts are reported in parts per million relative to residual $\mathrm{CHCl}_{3}$ in $\mathrm{CDCl}_{3}$ (7.26 and $77.16 \mathrm{ppm}$ ) or residual $\mathrm{CH}_{3} \mathrm{OH}$ in $\mathrm{CD}_{3} \mathrm{OD}$ (3.31 and $49.00 \mathrm{ppm}$ ). NMR coupling constants $(J)$ are reported in hertz. Infrared (IR) spectra were recorded using FTIR-8400S Shimadzu apparatus. Products were analyzed as thin films deposited on an $\mathrm{Se}-\mathrm{Zn}$ crystal by evaporation from $\mathrm{CH}_{2} \mathrm{Cl}_{2}$ solutions. For precursors, mono-acylated and bis-acylated compounds High Resolution Mass Spectrometry (HRMS) analyses were performed at the University of Mons Hainaut (Belgium) or at the University College London (UK). For compounds issued from RCM, low and high resolution mass spectrometry were performed at UCL on LTQOrbitrap-XL equipment. For compounds 14-21, only the ${ }^{13} \mathrm{C}$ NMR spectra are given.

\subsection{Synthesis of precursors $9 c, 10 c, 11 c, 12 c$, and $13 c$}

4.2.1. (S)-tert-Butyl hept-6-enoyl(1-hept-6-enoyl-2-oxoazetidin-3yl)carbamate (9c). A stirred solution of $\beta$-lactam 4 (300 mg, $1.61 \mathrm{mmol})$ in anhydrous THF $(11 \mathrm{~mL})$ was cooled to $-78{ }^{\circ} \mathrm{C}$. LiHMDS $1 \mathrm{~N}$ in hexane ( $3.54 \mathrm{~mL}, 3.54 \mathrm{mmol}$ ) was slowly added and the mixture was stirred for $30 \mathrm{~min}$. 6-Heptenoyl chloride $(592 \mathrm{mg}$, $3.54 \mathrm{mmol}$ ) was then added by syringe and the mixture was stirred for another $30 \mathrm{~min}$. The mixture was then warmed to rt over $4 \mathrm{~h}$ and then quenched with saturated $\mathrm{NH}_{4} \mathrm{Cl}(20 \mathrm{~mL})$. The resulting mixture was extracted with EtOAc $(2 \times 20 \mathrm{~mL})$ and the organic layers were washed with a saturated $\mathrm{NaHCO}_{3}$ solution $(50 \mathrm{~mL})$, and brine $\left(50 \mathrm{~mL}\right.$ ). After drying over $\mathrm{MgSO}_{4}$ and removing the solvent under reduced pressure, the residue was purified by flash column chromatography (hexane/EtOAc 4/1), to provide $9 \mathrm{c}$ as a pale-yellow oil (366 mg, 56\%). $R_{f}=0.58$ (hexane/EtOAc 4/1); $[\alpha]_{\mathrm{D}}^{20}+1.4($ c 3.0, $\left.\mathrm{CHCl}_{3}\right) ;{ }^{1} \mathrm{H}$ NMR $\left(300 \mathrm{MHz}, \mathrm{CDCl}_{3}\right): \delta=5.72-5.86(\mathrm{~m}, 3 \mathrm{H})$, $4.92-5.03(\mathrm{~m}, 4 \mathrm{H}), 3.83(\mathrm{~m}, 1 \mathrm{H}), 3.61(\mathrm{dd}, J=4.2,7.1 \mathrm{~Hz}, 1 \mathrm{H}), 2.88(\mathrm{~m}$, $2 \mathrm{H}), 2.73(\mathrm{~m}, 2 \mathrm{H}), 2.07(\mathrm{~m}, 4 \mathrm{H}), 1.60-1.74(\mathrm{~m}, 4 \mathrm{H}), 1.51(\mathrm{~s}, 9 \mathrm{H})$, $1.38-1.48 \mathrm{ppm}(\mathrm{m}, 4 \mathrm{H}) ;{ }^{13} \mathrm{C}\left(75 \mathrm{MHz}, \mathrm{CDCl}_{3}\right): \delta=175.5,171.2,164.5$, $151.2,138.5,138.4,114.8(2 \mathrm{C}), 85.6,56.9,43.9,38.2,36.5,33.6,33.5$, 28.4, 27.9 (2C), 24.4, 23.5 ppm; IR: $\nu=2860-3076,1798,1747$, $1697 \mathrm{~cm}^{-1}$; HRMS: calcd for $\mathrm{C}_{22} \mathrm{H}_{34} \mathrm{~N}_{2} \mathrm{O}_{5} \mathrm{Na} 429.2365$, found 429.2382 .

4.2.2. (S)-tert-Butyl 1-hept-6-enoyl-2-oxoazetidin-3-ylcarbamate (10c). To a stirred solution of $\beta$-lactam $4(427 \mathrm{mg}, 2.29 \mathrm{mmol})$ in dry $\mathrm{CH}_{2} \mathrm{Cl}_{2}(19 \mathrm{~mL})$ were added pyridine $(0.37 \mathrm{~mL}, 4.59 \mathrm{mmol})$ and 6-heptenoyl chloride ( $673 \mathrm{mg}, 4.59 \mathrm{mmol}$ ). The mixture was stirred for $24 \mathrm{~h}$ at rt and then diluted with $\mathrm{CH}_{2} \mathrm{Cl}_{2}(30 \mathrm{~mL})$ and the organic layer was washed with $\mathrm{HCl} 2 \mathrm{M}$ solution $(50 \mathrm{~mL})$, a saturated $\mathrm{NaHCO}_{3}$ solution $(50 \mathrm{~mL})$, and brine $(50 \mathrm{~mL})$. After drying over $\mathrm{MgSO}_{4}$ and removing the solvent under reduced pressure, the residue was purified by flash column chromatography (hexane/ EtOAc 4/1), to provide 10c as a colorless solid (523 $\mathrm{mg}, 77 \%$ ). $R_{f}=0.45$ (hexane/EtOAc 3/2); mp 92.9-93.6 ${ }^{\circ} \mathrm{C} ;[\alpha]_{\mathrm{D}}^{20}+11.3$ (c 2.6, $\left.\mathrm{CHCl}_{3}\right) ;{ }^{1} \mathrm{H} \mathrm{NMR}\left(300 \mathrm{MHz}, \mathrm{CDCl}_{3}\right): \delta=5.78(\mathrm{~m}, 1 \mathrm{H}), 5.17$ (d, $J=7.6 \mathrm{~Hz}, 1 \mathrm{H}), 4.92-5.03(\mathrm{~m}, 2 \mathrm{H}), 4.44$ and $4.66(2 \mathrm{br} \mathrm{s}, 1 \mathrm{H}$, rotamers), $3.86(\mathrm{~m}, 1 \mathrm{H}), 3.64(\mathrm{dd}, J=3.9,7.6 \mathrm{~Hz}, 1 \mathrm{H}), 2.72(\mathrm{~m}, 2 \mathrm{H})$, $2.07(\mathrm{~m}, 2 \mathrm{H}), 1.67(\mathrm{~m}, 2 \mathrm{H}), 1.40-1.49 \mathrm{ppm}(\mathrm{m}, 11 \mathrm{H}) ;{ }^{13} \mathrm{C}(75 \mathrm{MHz}$, $\left.\mathrm{CDCl}_{3}\right): \delta=171.3,165.2,154.7,138.5,114.8,81.2,56.6,45.6,36.6,33.5$, $28.4,28.3,23.5$ ppm; IR: $\nu=3354,2864-2976,1796,1689$, $1518 \mathrm{~cm}^{-1}$; HRMS: calcd for $\mathrm{C}_{15} \mathrm{H}_{24} \mathrm{~N}_{2} \mathrm{O}_{4} \mathrm{Na} 319.1634$, found 319.1636.

4.2.3. (S)-tert-Butyl 1-hept-6-enoyl-2-oxoazetidin-3-yl(methyl)carbamate (11c). Compound 11c was synthesized according to the procedure described above for the synthesis of compound $10 \mathrm{c}$ from $\beta$-lactam 8 (250 mg, $1.24 \mathrm{mmol}$ ) and 6-heptenoyl chloride and the mixture was put under reflux for $24 \mathrm{~h}$. Flash column chromatography (hexane/EtOAc 4/1) provided 11c as a colorless oil (336 mg, $87 \%) . R_{f}=0.53$ (hexane/EtOAc 3/2); $[\alpha]_{\mathrm{D}}^{20}+11.5\left(\right.$ c 5.0, $\left.\mathrm{CHCl}_{3}\right) ;{ }^{1} \mathrm{H}$ $\operatorname{NMR}\left(300 \mathrm{MHz}, \mathrm{CDCl}_{3}\right): \delta=5.76(\mathrm{~m}, 1 \mathrm{H}), 4.91-5.06(\mathrm{~m}, 2 \mathrm{H}+0.5 \mathrm{H}$, rotamer), 4.60 (br s, $0.5 \mathrm{H}$, rotamer), $3.80(\mathrm{~m}, 1 \mathrm{H}), 3.61$ (dd, $J=3.9$, $7.5 \mathrm{~Hz}, 1 \mathrm{H}), 2.92$ (br s, 3H), 2.71 (br s, $2 \mathrm{H}), 2.05(\mathrm{~m}, 2 \mathrm{H}), 1.66(\mathrm{~m}, 2 \mathrm{H})$, $1.43 \mathrm{ppm}$ (br s, $11 \mathrm{H}) ;{ }^{13} \mathrm{C}\left(75 \mathrm{MHz}, \mathrm{CDCl}_{3}\right): \delta=171.3,164.9$, 154.3-154.9 (rotamers), 138.4, 114.8, 81.4-82.1 (rotamers), 62.9-63.7 (rotamers), 43.2-44.4 (rotamers), 36.5, 35.2-33.5 (rotamers), 33.5, 28.3, 28.2, 23.5 ppm; IR: $\nu=2864-2976,1794$, $1693,1639 \mathrm{~cm}^{-1}$; HRMS: calcd for $\mathrm{C}_{16} \mathrm{H}_{26} \mathrm{~N}_{2} \mathrm{O}_{4} \mathrm{Na} 333.1790$, found 333.1796.

4.2.4. (S)-N-(1-Hept-6-enoyl-2-oxoazetidin-3-yl)hept-6-enamide (12c). Trifluoroacetic acid $(0.75 \mathrm{~mL}, 10.12 \mathrm{mmol})$ was added to $10 \mathrm{c}$ ( $150 \mathrm{mg}, 0.51 \mathrm{mmol}$ ) dissolved in $\mathrm{CH}_{2} \mathrm{Cl}_{2}(5 \mathrm{~mL})$ at $0{ }^{\circ} \mathrm{C}$. The mixture was warmed to $\mathrm{rt}$ and stirred for $2 \mathrm{~h}$. Concentration of the reaction solution afforded the crude trifluoroacetate salt as a viscous oil. Then 6-heptenoyl chloride ( $111 \mathrm{mg}, 0.76 \mathrm{mmol}$ ) was added to a stirred solution of the crude trifluoroacetate salt and triethylamine $(0.21 \mathrm{~mL}, 1.58 \mathrm{mmol})$ in $\mathrm{CH}_{2} \mathrm{Cl}_{2}(5 \mathrm{~mL})$ cooled at $0{ }^{\circ} \mathrm{C}$. The mixture was then warmed to $\mathrm{rt}$ and stirred overnight. The mixture was then diluted with $\mathrm{CH}_{2} \mathrm{Cl}_{2}(25 \mathrm{~mL})$, and sequentially washed with $\mathrm{HCl} 2 \mathrm{M}$ solution $(30 \mathrm{~mL})$, a saturated $\mathrm{NaHCO}_{3}$ solution $(30 \mathrm{~mL})$, and brine $(40 \mathrm{~mL})$. After drying over $\mathrm{MgSO}_{4}$ and removing the solvent under reduced pressure, the residue was purified by flash column chromatography (hexane/EtOAc 3/2), to provide 12c as a colorless solid (129 mg, 83\%). $R_{f}=0.34$ (hexane/EtOAc $1 / 1$ ); mp 97.2-98.5 ${ }^{\circ} \mathrm{C} ;[\alpha]_{\mathrm{D}}^{20}+13.4\left(\right.$ c $\left.3.0, \mathrm{CHCl}_{3}\right) ;{ }^{1} \mathrm{H} \mathrm{NMR}\left(300 \mathrm{MHz}, \mathrm{CDCl}_{3}\right)$ : $\delta=6.21(\mathrm{~d}, J=7.0 \mathrm{~Hz}, 1 \mathrm{H}), 5.77(\mathrm{~m}, 2 \mathrm{H}), 4.92-5.03(\mathrm{~m}, 4 \mathrm{H}), 4.70(\mathrm{td}$, 
$J=3.9,6.9 \mathrm{~Hz}, 1 \mathrm{H}), 3.85(\mathrm{~m}, 1 \mathrm{H}), 3.66(\mathrm{dd}, J=3.9,7.4 \mathrm{~Hz}, 1 \mathrm{H}), 2.72(\mathrm{~m}$, $2 \mathrm{H}), 2.24(\mathrm{t}, J=7.5 \mathrm{~Hz}, 2 \mathrm{H}), 2.02-2.10(\mathrm{~m}, 4 \mathrm{H}), 1.59-1.72(\mathrm{~m}, 4 \mathrm{H})$, $1.36-1.50 \mathrm{ppm}(\mathrm{m}, 4 \mathrm{H}) ;{ }^{13} \mathrm{C}\left(75 \mathrm{MHz}, \mathrm{CDCl}_{3}\right): \delta=173.6,171.3,164.7$, $138.4,138.3,115.0,114.8,55.8,45.0,36.5,35.8,33.5$ (2C), $28.4(2 \mathrm{C})$, 24.8, 23.5 ppm; IR: $\nu=3290,2852-3080,1797,1780,1693,1651$, $1537 \mathrm{~cm}^{-1}$; HRMS: calcd for $\mathrm{C}_{17} \mathrm{H}_{26} \mathrm{~N}_{2} \mathrm{O}_{3} \mathrm{Na}$ 329.1841, found 329.1846.

4.2.5. (S)-N-(1-Hept-6-enoyl-2-oxoazetidin-3-yl)-N-(methyl)hept-6enamide (13c). Compound 13c was synthesized according to the procedure described above for the synthesis of compound $12 \mathrm{c}$ from $\beta$-lactam 11c (336 mg, $1.08 \mathrm{mmol}$ ) and 6-heptenoyl chloride. Flash column chromatography (hexane/EtOAc $3 / 2$ ) provided $13 \mathrm{c}$ as a colorless oil $(263 \mathrm{mg}, 76 \%) . R_{f}=0.28$ (hexane/EtOAc $\left.3 / 2\right) ;[\alpha]_{\mathrm{D}}^{20}$ +13.3 (c 3.5, $\left.\mathrm{CHCl}_{3}\right) ;{ }^{1} \mathrm{H}$ NMR $\left(300 \mathrm{MHz}, \mathrm{CDCl}_{3}\right): \delta=5.77(\mathrm{~m}, 2 \mathrm{H})$, 4.89-5.02 (m, 5H), $3.81(\mathrm{~m}, 1 \mathrm{H}), 3.63(\mathrm{dd}, J=3.9,7.4 \mathrm{~Hz}, 1 \mathrm{H}), 3.05(\mathrm{~s}$, $3 \mathrm{H}), 2.73(\mathrm{~m}, 2 \mathrm{H}), 2.34(\mathrm{~m}, 2 \mathrm{H}), 2.06(\mathrm{~m}, 4 \mathrm{H}), 1.66(\mathrm{~m}, 4 \mathrm{H}), 1.43 \mathrm{ppm}$ $(\mathrm{m}, 4 \mathrm{H}) ;{ }^{13} \mathrm{C}\left(75 \mathrm{MHz}, \mathrm{CDCl}_{3}\right): \delta=173.8,171.3,164.4,138.5,138.4$, 114.9, 114.8, 62.9, 43.1, 36.5, 35.4, 33.6, 33.5, 33.4, 28.6, 28.4, 24.1, 23.5 ppm; IR: $\nu=2858-3074,1790,1738,1703,1651 \mathrm{~cm}^{-1}$; MS (APCI): $m / z$ : 320.95 (M); HRMS: calcd for $\mathrm{C}_{18} \mathrm{H}_{29} \mathrm{~N}_{2} \mathrm{O}_{3} 321.21782$, found 321.21822 .

\subsection{General procedure for $\mathrm{RCM}$}

Grubbs catalyst (second generation) ( 0.05 equiv) was added to a stirred solution of $\beta$-lactam (1 equiv) in dry $\mathrm{CH}_{2} \mathrm{Cl}_{2}(5 \mathrm{mM})$ and the solution was stirred at reflux under argon for $4 \mathrm{~h}$. Then a second addition of Grubbs catalyst ( 0.05 equiv) was made and then reaction was additionally stirred at reflux for $20 \mathrm{~h}$. Then the solvent was removed under reduced pressure and the crude product was purified thrice by column chromatography (hexane/EtOAc), to provide products as pale-brown oil.

4.3.1. (S)-tert-Butyl 2,13,16-trioxo-1,14-diazabicyclo[13.1.1]heptadec7-ene-14-carboxylate (14c). Yield: $9 \%$ (43 $\mathrm{mg}$ from $1.22 \mathrm{mmol}$ of 9c). $R_{f}=0.51$ (hexane/EtOAc $7 / 3$ ); $[\alpha]_{\mathrm{D}}^{20}-32.4\left(\right.$ c 2.8, $\left.\mathrm{CHCl}_{3}\right) ;{ }^{13} \mathrm{C}$ $\left(125 \mathrm{MHz}, \mathrm{CDCl}_{3}\right): \delta=176.6,172.6,164.2,151.3,131.1,130.6,85.4$, 59.7, 44.6, 38.3, 38.2, 32.1, 31.5, 30.5, 28.9, 28.1, 24.8, 22.7 ppm; IR: $\nu=2854-2976,1799,1738,1697 \mathrm{~cm}^{-1}$; HRMS: calcd for $\mathrm{C}_{20} \mathrm{H}_{30} \mathrm{~N}_{2} \mathrm{O}_{5} \mathrm{Na}$ 401.20469, found 401.20442.

4.3.2. Compound (15b). Yield: $44 \%$ (229 $\mathrm{mg}$ from $1.47 \mathrm{mmol}$ of $\mathbf{9 b}$ ). $R_{f}=0.53$ (hexane/EtOAc 3/2); $[\alpha]_{\mathrm{D}}^{20}-9.1\left(\right.$ c 3.0, $\left.\mathrm{CHCl}_{3}\right) ;{ }^{13} \mathrm{C}(75 \mathrm{MHz}$, $\left.\mathrm{CDCl}_{3}\right): \delta=175.7,175.4,171.4,164.1,163.9,151.4,151.3,85.5,85.1$, 57.8, 57.5, 43.8, 43.7, 37.7, 37.4, 34.8, 31.9, 31.8, 31.7, 31.5, 28.0, 24.5, 22.6 ppm; IR: $\nu=2853-2970,1797,1744,1701 \mathrm{~cm}^{-1}$; HRMS: calcd for $\mathrm{C}_{36} \mathrm{H}_{52} \mathrm{~N}_{4} \mathrm{O}_{10} \mathrm{Na}$ 723.35756, found 723.35643.

4.3.3. Compound (15c). Yield: $10 \%$ ( $46 \mathrm{mg}$ from $1.22 \mathrm{mmol}$ of $\mathbf{9 c}$ ). $R_{f}=0.45$ (hexane/EtOAc 7/3); $[\alpha]_{\mathrm{D}}^{20}+5.8$ (c 4.4, $\left.\mathrm{CHCl}_{3}\right) ;{ }^{13} \mathrm{C}$ $\left(125 \mathrm{MHz}, \mathrm{CDCl}_{3}\right): \delta=175.6,175.5,171.5,171.4,164.5,164.4,151.4$, $151.3,130.7,130.6,130.5,130.3,85.5,57.4,57.2,43.9,43.8,38.4,38.2$, $36.5,32.3,32.2,32.1,28.8,28.7,28.0,24.1,24.0,23.7,23.4$ ppm; IR: $\nu=2856-2928,1799,1742,1697 \mathrm{~cm}^{-1}$; HRMS: calcd for $\mathrm{C}_{40} \mathrm{H}_{60} \mathrm{~N}_{4} \mathrm{O}_{10} \mathrm{Na}$ 779.42017, found 779.41947.

4.3.4. Compound (16b). Yield: $35 \%$ (30 $\mathrm{mg}$ from $0.34 \mathrm{mmol}$ of $\mathbf{1 2 b}$ ). $R_{f}=0.32$ (EtOAc); $[\alpha]_{\mathrm{D}}^{20}-15.6$ (c 2.2, $\left.\mathrm{CHCl}_{3}\right) ;{ }^{13} \mathrm{C}\left(75 \mathrm{MHz}, \mathrm{CDCl}_{3}\right)$ : $\delta=174.4,171.0,165.8,131.5,130.8,55.7,46.0,35.4,34.5,31.8,31.6$, 24.3, 22.0 ppm; IR: $\nu=3284-3387,2906-2930,1784,1693,1676$, $1655,1527 \mathrm{~cm}^{-1}$; HRMS: calcd for $\mathrm{C}_{26} \mathrm{H}_{36} \mathrm{~N}_{4} \mathrm{O}_{6} \mathrm{Na} 523.25271$, found 523.25171 .

4.3.5. Compound (16c). Yield: $28 \%$ ( $46 \mathrm{mg}$ from $0.42 \mathrm{mmol}$ of $\mathbf{1 2 c}$ ). $R_{f}=0.48$ (EtOAc); $[\alpha]_{\mathrm{D}}^{20}+13.3\left(\right.$ c $\left.2.4, \mathrm{CHCl}_{3}\right) ;{ }^{13} \mathrm{C}\left(125 \mathrm{MHz}, \mathrm{CDCl}_{3}\right)$ : $\delta=174.2,173.8,172.4,171.7,165.5,164.9,130.9,130.8,130.6,130.0$, 55.6, 55.2, 45.4, 45.1, 36.8, 36.5, 36.3, 36.1, 31.9, 31.8, 31.7, 28.4, 28.3, 28.2, 28.1, 24.7, 24.4, 23.3, 22.8 ppm; IR: $\nu=3323,2926,2854,1796$, $1697,1678,1533 \mathrm{~cm}^{-1}$; HRMS: calcd for $\mathrm{C}_{30} \mathrm{H}_{44} \mathrm{~N}_{4} \mathrm{O}_{6} \mathrm{Na} 579.31531$, found 579.31433 .

4.3.6. Compound (17b). Yield: $43 \%$ ( $78 \mathrm{mg}$ from $0.69 \mathrm{mmol}$ of $\mathbf{1 3 b}$ ). $R_{f}=0.46$ (EtOAc); $\left.[\alpha]\right]_{\mathrm{D}}^{20}-10.7$ (c 1.1, $\left.\mathrm{CHCl}_{3}\right) ;{ }^{13} \mathrm{C}\left(125 \mathrm{MHz}, \mathrm{CDCl}_{3}\right)$ : $\delta=174.1,171.4,164.5,131.4,130.9,130.6,130.4,63.0,61.9,43.1,36.0$, 35.4, 35.2, 35.1, 32.5, 31.9, 31.6, 31.4, 24.1, 24.0, 23.4, 22.8 ppm; IR: $\nu=2851-2976,1790,1695,1651 \mathrm{~cm}^{-1}$; HRMS: calcd for $\mathrm{C}_{28} \mathrm{H}_{40} \mathrm{~N}_{4} \mathrm{O}_{6} \mathrm{Na}$ 551.28401, found 551.28341.

4.3.7. Compound (17c). Yield: $40 \%$ (20 $\mathrm{mg}$ from $0.17 \mathrm{mmol}$ of 13c) $R_{f}=0.47$ (EtOAc); $[\alpha]_{\mathrm{D}}^{20}-9.1\left(\right.$ c 3.0, $\left.\mathrm{CHCl}_{3}\right) ;{ }^{13} \mathrm{C}\left(125 \mathrm{MHz}, \mathrm{CDCl}_{3}\right)$ : $\delta=174.0,173.9,171.6,164.5,164.4,130.6,130.5,130.4,130.2,63.1$, 62.5, 43.2, 43.1, 36.6, 36.5, 33.6, 33.5, 33.4, 32.3, 32.1, 32.0, 29.2, 29.0, 28.9, 28.8, 23.9, 23.8, 23.6, 23.5 ppm; IR: $\nu=2851-3003,1786$, $1736,1716 \mathrm{~cm}^{-1}$; HRMS: calcd for $\mathrm{C}_{32} \mathrm{H}_{48} \mathrm{~N}_{4} \mathrm{O}_{6} \mathrm{Na} 607.34661$, found 607.34582 .

\section{Acknowledgements}

This work was supported by the Interuniversity Attraction Pole (IAP P6/19 PROFUSA), F.R.S.-FNRS, UCL and ULg (computational facilities). G.D. and J.M.-B. are senior research associates of the F.R.S.-FNRS (Belgium). J.-L.H.J. thanks the Belgian National Fund for Scientific Research (FNRS) (FRFC 2.4555.08), the Special Fund for Research (FSR) and the faculty of medicine of UCL for financial support on this research (LTQ-Orbitrap). Dr. Astrid Zervosen is acknowledged for the R39 testing. Ir. Raoul Rozenberg, Dr. Cécile Le Duff and Dr. Marie-France Hérent have contributed to the structural analysis.

\section{Supplementary data}

The Supplementary data for this paper includes experimental details for compounds $\mathbf{6}-\mathbf{8}, \mathbf{1 8}-\mathbf{2 1}$, structural data for compounds 6-8, 9a, b-13a, b, 18c, 19b, c-21b, c, NMR spectra of all new compounds, ESI and APCI mass spectra for compounds 14c, 15b, $\mathbf{c}-\mathbf{1 7 b} \mathbf{b}, \mathbf{c}$, generation of conformers, graphics of relative energies of precursors/cyclic monomers, heat of formation for precursors $\mathbf{9 a}-\mathbf{c}, \mathbf{1 2 a}-\mathbf{c}$ and $13 \mathbf{a}-\mathbf{c}$, and testing protocol versus R39. Supplementary data related to this article can be found online at doi:10.1016/j.tet.2010.10.015.

\section{References and notes}

1. (a) Gradillas, A.; Pérez-Castells, J. Angew. Chem., Int. Ed. 2006, 45, 6086-6101; (b) Conrad, J. C.; Fogg, D. E. Curr. Org. Chem. 2006, 10, 185-202; (c) Majumdar, K. C.; Rahaman, H.; Roy, B. Curr. Org. Chem. 2007, 11, 1339-1365; (d) Clavier, H.; Grela, K.; Kirshning, A.; Mauduit, M.; Nolan, S. P. Angew. Chem., Int. Ed. 2007, 46 6786-6801; (e) Nicolaou, K. C.; Bulger, P. G.; Sarlah, D. Angew. Chem., Int. Ed. 2005, 44, 4490-4527; (f) Brik, A. Adv. Synth. Catal. 2008, 350, 1661-1675.

2. (a) Monfette, S.; Fogg, D. E. Chem. Rev. 2009, 109, 3783-3816; (b) Monfette, S.; Crane, A. K.; Duarte Silva, J. A.; Facey, G. A.; dos Santos, E. N.; Araujo, M. H.; Fogg, D. E. Inorg. Chim. Acta 2010, 363, 481-486.

3. (a) Creighton, C. J.; Leo, G. C.; Du, Y.; Reitz, A. B. Bioorg. Med. Chem. 2004, 12 , 4375-4385; (b) Chen, G.; Kirschning, A. Chem.—Eur. J. 2002, 8, 2717-2729.

4. (a) Tzur, E.; Ben-Asuly, A.; Diesendruck, C. E.; Goldberg, I; Lemcoff, N. G. Angew. Chem., Int. Ed. 2008, 47, 6422-6425; (b) Diesendruck, C. E.; Ben-Asuly, A.; Goldberg, I.; Lemcoff, N. G. Chim. Oggi 2010, 28, 15-18.

5. Pandian, S.; Hillier, I. H.; Vincent, M. A.; Burton, N. A.; Ashworth, I. W.; Nelson, D. J.; Percy, J. M.; Rinaudo, G. Chem. Phys. Lett. 2009, 476, 37-40.

6. (a) Urbach, A.; Dive, G.; Marchand-Brynaert, J. Eur. J. Org. Chem. 2009, 11 1757-1770; (b) Urbach, A.; Dive, G.; Tinant, B.; Duval, V.; Marchand-Brynaert, J. Eur. J. Med. Chem. 2009, 44, 2071-2080.

7. Miller, M. J.; Mattingly, P. G.; Morrison, M. A.; Kerwin, J. F., Jr. J. Am. Chem. Soc. 1980, 102, 7026-7032

8. Qabar, M. N.; Kahn, M. Tetrahedron Lett. 1996, 37, 965-968. 
9. Structural description given by Mattingly, P. G.; Miller, M. J. J. Org. Chem. 1980, 45, 410-415

10. Prashad, M.; Har, D.; Hu, B.; Kim, H.-Y.; Repic, O.; Blacklock, T. J. Org. Lett. 2003, $5,125-128$.

11. (a) Ahrendt, K. A.; Williams, R. M. Org. Lett. 2004, 24, 4539-4541; (b) Gaul, C.; Njardarson, J. T.; Shan, D.; Dorn, D. C.; Wu, K.; Tong, W. P.; Huang, X.; Moore, M. A. S.; Danishefsky, S. J. J. Am. Chem. Soc. 2004, 126, 11326-11337.

12. Fürstner, A.; Langemann, K. J. Am. Chem. Soc. 1997, 119, 9130-9136.

13. Yamamoto, K.; Biswas, K.; Gaul, C.; Danishefsky, S. Tetrahedron Lett. 2003, 44, 3297-3299.

14. (a) Knops, P.; Sendhoff, N.; Mekelburger, B.; Voegtle, F. Top. Curr. Chem. 1991, 161, 1-36; (b) Illumani, G.; Mandolini, L. Acc. Chem. Res. 1981, 14, 95-102.

15. Francl, M. M.; Pietro, W. J.; Hehre, W. J.; Binkley, J. S.; DeFrees, D. J.; Pople, J. A.; Gordon, M. S. J. Chem. Phys. 1982, 77, 3654-3666.

16. Frisch, M. J.; Trucks, G. W.; Schlegel, H. B.; Scuseria, G. E.; Robb, M. A.; Cheeseman, J. R.; Montgomery, J. A., Jr.; Vreven, T.; Kudin, K. N.; Burant, J. C. Millam, J. M.; Iyengar, S. S.; Tomasi, J.; Barone, V.; Mennucci, B.; Cossi, M.; Scalmani, G.; Rega, N.; Petersson, G. A.; Nakatsuji, H.; Hada, M.; Ehara, M.; Toyota, K.; Fukuda, R.; Hasegawa, J.; Ishida, M.; Nakajima, T.; Honda, Y.; Kitao, O.; Nakai, H.; Klene, M.; Li, X.; Knox, J. E.; Hratchian, H. P.; Cross, J. B.; Adamo, C.; Jaramillo, J.; Gomperts, R.; Stratmann, R. E.; Yazyev, O.; Austin, A. J.; Cammi, R.; Pomelli, C.; Ochterski, J. W.; Ayala, P. Y.; Morokuma, K.; Voth, G. A.;
Salvador, P.; Dannenberg, J. J.; Zakrzewski, V. G.; Dapprich, S.; Daniels, A. D.; Strain, M. C.; Farkas, O.; Malick, D. K.; Rabuck, A. D.; Raghavachari, K.; Foresman, J. B.; Ortiz, J. V.; Cui, Q; Baboul, A. G.; Clifford, S.; Cioslowski, J.; Stefanov, B. B.; Liu, G.; Liashenko, A.; Piskorz, P.; Komaromi, I.; Martin, R. L.; Fox, D. J.; Keith, T.; Al-Laham, M. A.; Peng, C. Y.; Nanayakkara, A.; Challacombe, M.; Gill, P. M. W.; Johnson, B.; Chen, W.; Wong, M. W.; Gonzalez, C.; Pople, J. A. Gaussian 03, Revision D.02; Gaussian: Wallingford CT, 2004.

17. Dunning T. H., Jr.; Hay, P. J. In Modern Theoretical Chemistry; Schaefer, H. F., III, Ed.; PLENUM: New York, NY, 1976; Vol. 3, pp 1-28.

18. Sauvage, E.; Herman, R.; Petrella, S.; Duez, C.; Bouillenne, F.; Frère, J.-M.; Charlier, P. J. Biol. Chem. 2005, 280, 31249-31256.

19. (a) Schwyzer, R.; Hurlimann, C. Coenzyle, C. Helv. Chim. Acta 1954, 37, 155-166; (b) Adam, M.; Damblon, C.; Plaitin, B.; Christiaens, L.; Frère, J.-M. Biochem. J. 1990, 270, 525-529.

20. Lakaye, B.; Damblon, C.; Jamin, M.; Galleni, M.; Lepage, S.; Joris, B.; MarchandBrynaert, J.; Frydrych, C.; Frère, J.-M. Biochem. J. 1994, 300, 141-145.

21. Zervosen, A.; Lu, W.-P.; Chen, Z.; White, R. E.; Demuth, T. P., Jr.; Frère, J.-M. Antimicrob. Agents Chemother. 2004, 48, 961-969.

22. (a) Woodward, R. B. Phil. Trans. R. Soc. Lond. (B) 1980, 289, 239-250; (b) Cohen, N. C. J. Med. Chem. 1983, 26, 259-264; (c) Bruton, G. Bioorg. Med. Chem. Lett. 1993, 3, 2329-2332.

23. El-azizi, Y.; Schmitzer, A.; Collins, S. K. Angew. Chem., Int. Ed. 2006, 45, 968-973. 